\title{
Tandem Reactions Using Nitrile Imines: Synthesis of Some Novel Heterocyclic Compounds with Expected Biological Activity
}

\author{
ADIL A. H. GOBOURI', \\ MOSSELHI A.N. M. MOHAMED*1,2 and MAHMOUD A. AMIN ${ }^{1,3}$ \\ ${ }^{1}$ Department of Chemistry, Faculty of Science, Taif University, 21974-Taif/haweiah, Saudi Arabia. \\ ${ }^{2}$ Department of Chemistry, Faculty of Science, Cairo University, 12613-Giza, Egypt. \\ ${ }^{3}$ Department of Chemistry, Faculty of Science, Suez Canal University, Ismailia, Egypt. \\ *Corresponding author E-mail: mosselhimohamed@yahoo.com \\ http://dx.doi.org/10.13005/ojc/320115 \\ (Received: January 29, 2016; Accepted: March 01, 2016)

\section{ABSTRACT} \\ New functionalized 7,9-dimethylpyrimido[4,5- $d][1,2,4]$ triazolo[4,3-a]pyrimidine- \\ $5,6,8(1 H, 7 H, 9 H)$-trione derivatives were synthesized via reaction of the hydrazonoyl halides with \\ 7,8-dihydro-1,3-dimethyl-7-thioxopyrimido[4,5- $d$ ]pyrimidine-2,4,5(1H,3H,6H)trione. The biological \\ activity of the products has been evaluated. The mechanism and the regioselectivity of the studied \\ reactions have been discussed.
}

Key words: Tandem reaction, hydrazonoyl halides, nitrile imines, I,3-dipolar cycloaddition, heterocycles, biological activity.

\section{INTRODUCTION}

Chemists are constantly working to discover new and improved reactions. One of the primary motivating goals of this research is the development of cleaner, more efficient transformations to shorten syntheses and save money on chemicals. The strategy of using reactions in tandem is also aimed at shortening syntheses. Tandem reactions are commonly referred to under the nebulous phrase "multistep one-pot reactions". ${ }^{1}$ On cost and amounts of reagents, solvents, and reduce the amount of waste that is generated. So, our aim is to use such idea of tandem reactions of organic compounds to synthesize new heterocycles with expected biological activity in short steps by using nitrile imines via 1,3-dipolar cycloaddition. 
Basically a nitrile imine 1 is a flexible system of three atoms over which four pi-electrons are distributed. Although one can write seven possible resonance structures for such a system, the 1,3dipolar sextet structure 1A with its complementary nucleophilic and electrophilic centers will be used throughout this article, although theoretical calculations have indicated that all the octet zwitterionic structure 1B is the most stable contributor to the resonance hybrid. ${ }^{2}$
$R-\stackrel{\oplus}{\mathrm{C}}=\mathrm{N}-\stackrel{\ominus}{\mathrm{N}}-\mathrm{R}^{\prime}$

$1 \mathrm{~A}$

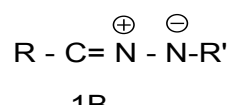

1B
As very authorative review of the chemistry of the precursors of nitriliminesas well as generation of nitrile imines was reported in 2010 by Shawali. ${ }^{2}$ Pyridopyrimidines have good biological importance. ${ }^{3}$ Recently some fused heterocyclic compounds containing nitrogen atom show a wide range of pharmacological activities. Pyrimidopyrimidines are annelated to uracils that have considerable interest in recent years. ${ }^{4,5}$ Derivatives of pyrimidopyrimidine display potent inhibitory properties regarding tyrosine kinase domain of epidermalgrowth factor receptor. ${ }^{6}$ Pyrimido[4,5-d]pyrimidine fused system represent attractive pharmacological applications such as antitumor, ${ }^{7}$ antiviral, ${ }^{8}$ antioxidant, ${ }^{9}$ antifungal ${ }^{10}$ and hepatoprotective activities. ${ }^{11}$ Pyrimidopyrimidines have a ring system that can be found marine derived natural products such as crambescidin 23 alkaloid. Keeping this importance in mind herein the reactions of 7-thioxopyrimdo[4,5-d]pyrimidin-2,4,5-trione with hydrazonoyl halides will be reported.

\section{EXPERIMENTAL}

\section{General}

All evaporations were carried out under reduced pressure at $60^{\circ} \mathrm{C}$. TLC was carried out on aluminum sheet silica gel 60 (Fluka) and detected by UV light. All melting points were measured on an electrothermal melting point apparatus and are uncorrected. The ${ }^{1} \mathrm{H}$ and ${ }^{13} \mathrm{C}$ NMR spectra were recorded in deuterated dimethyl sulphoxide (DMSOd6) at $300 \mathrm{MHz}$ on a Varian Mercury VXR-300 NMR spectrometer (Cairo University). Chemical shifts were related to that of the solvent. The infrared spectra were recorded in potassium bromide discs on a Pye-Unicam, SP300 and Shimadzu, FT IR 8101 PC infrared spectrophotometers. Biological activity was carried out at the Microanalytical Center of Cairo University, Cairo, Egypt. Mass spectra were recorded on a Shimadzu GC MS-QP 1000 EX mass spectrometer at $70 \mathrm{e} . \mathrm{V}$. Elemental analyses were carried out at the Microanalytical Center of Cairo University, Giza, Egypt.

\section{MATERIALS}

\section{Synthesis of 7,8-dihydro-1,3-dimethyl-7- thioxopyrimido[4,5-d]pyrimidine-2,4,5(1H,3H,6H) trione (4)}

A mixture of ethyl 6-amino-1,3-dimethyl-5(ethoxycarbonyl)uracil (3) ${ }^{12}$ (11.35 g, 0.05 mole) and potassium thiocyanate $(6.8 \mathrm{~g}, 0.07 \mathrm{~mol})$ was stirred under reflux in dioxane $(40 \mathrm{ml})$ containing $10 \% \mathrm{HCl}$ $(40 \mathrm{ml})$ for 20 hours. After cooling, the mixture was poured into $300 \mathrm{ml}$ water, the solid precipitated was filtered off and crystallized from dioxane to give $\mathbf{4}$ as yellow powder.

Yield: 7.5 g, 62.5\%; m.p. > $300 \% \mathrm{C}$; IR 13150 (NH), 1705, 1680, 1630 (CO) cm"1; ' ${ }^{1} \mathrm{H}$ NMR(DMSOd6) $\delta 3.2\left(\mathrm{~s}, 3 \mathrm{H}, \mathrm{CH}_{3}\right), 3.45\left(\mathrm{~s}, 3 \mathrm{H}, \mathrm{CH}_{3}\right), 13.75$ (s, $2 \mathrm{H}, \mathrm{NH}) ;{ }^{13} \mathrm{C}$ NMR(DMSO-d6, $\left.75 \mathrm{Mz}\right) \delta 29.0\left(\mathrm{CH}_{3}\right)$, $30.5\left(\mathrm{CH}_{3}\right), 85.0(\mathrm{C} 4 \mathrm{a}), 150.5(\mathrm{C} 2), 161.0(\mathrm{C} 8 \mathrm{a})$, 162.0 (C4), 163.5 (C5), 173.0 (C=S); MS, m/z (\%) $240\left(\mathrm{M}^{+}, 40\right)$; Anal. Calcd for $\mathrm{C}_{8} \mathrm{H}_{8} \mathrm{~N}_{4} \mathrm{O}_{3} \mathrm{~S}$ (240.2): C, 40.00; H, 3.36; N, 23.32 ; S, 13.35. Found: C, 39.7; H, 3.2; N, 22.9; S, 13.0\%.

\section{Reactions of 4 with active chloromethylene compounds (10b,d,f)}

To a solution of $4(2.4 \mathrm{~g}, 0.01 \mathrm{~mol})$ in chloroform was added triethylamine $(1.4 \mathrm{ml}, 0.01$ $\mathrm{mol}$ ) and the mixture was stirred for $10 \mathrm{~min}$ at room temperature. To the resulting clear solution was added active chloromethylene derivative (10) (0.01 mol) dropwise while stirring the reaction mixture. After complete addition, the reaction mixture was stirred for further $24 \mathrm{~h}$ at room temperature. The solid that precipitated was filtered off, washed with water, dried and finally crystallized from dioxane to give pure 11. The compounds $\mathbf{1 1 b}, \mathbf{d}, \mathbf{f p r e p a r e d}$ are listed below together with their physical constants. 
1, 3 - D i m e t h y I - 2 , 4,5 ( 1 H , 3 H , 6 H ) trioxopyrimido[4,5-d]pyrimidin-7-yl] thio-2,4dioxopentane (11b)

Yellow solid (2.0 g, 59\%), m.p. $235 \%$ C; IR (KBr) í3400 (NH), 1712, 1702, 1651, $1632\left(\mathrm{C}^{\circ}\right) \mathrm{cm}^{\prime \prime}$; ${ }^{1} \mathrm{H}$ NMR (DMSO-d6) $\delta 2.0\left(\mathrm{~s}, 6 \mathrm{H}, 2 \mathrm{COCH}_{3}\right), 3.20$ (s, 3H, N-CH $\mathrm{CH}_{3}, 3.4\left(\mathrm{~s}, 3 \mathrm{H}, \mathrm{N}-\mathrm{CH}_{3}\right), 4.7(\mathrm{~s}, 1 \mathrm{H}, \mathrm{CH})$, 11.45 (s, $1 \mathrm{H}, \mathrm{NH}) ;{ }^{13} \mathrm{C}$ NMR(DMSO-d6, $\left.75 \mathrm{Mz}\right) \delta$ $20.2\left(2 \mathrm{CH}_{3}\right), 27.6\left(\mathrm{CH}_{3}\right), 29.5\left(\mathrm{CH}_{3}\right), 69.5(\mathrm{CH}), 95.8$ (C4a), 144.5 (C8a), 145.78 (C2), 154.5 (C7-S), 161.5 (C4), 168.76 (C5), $172.13\left(\mathrm{CH}_{3} \mathrm{CO}\right)$; MS m/z (\%) 338 $\left(\mathrm{M}^{+}, 17\right)$; Anal. Calcd for $\mathrm{C}_{13} \mathrm{H}_{14} \mathrm{~N}_{4} \mathrm{O}_{5} \mathrm{~S}$ (338.34): $\mathrm{C}$, 46.15; H, 4.17; N, 16.56; S, 9.48. Found C, 46.1; H, 3.9; N, 16.3; S, 9.5\%.

Ethyl 1,3-dimethyl-2, 4, 5 (1 H, 3 H, 6 H) trioxopyrimido[4,5-d]-pyrimidin-7-yl] thio-3oxobutanoate (11d).

Yellow solid (2.4 g, 65.0\%), m.p. $244^{\circ} \mathrm{C}$; IR (KBr) í3410 (NH), 1715, 1705, 1650, 1625 (CO) cm"1; ${ }^{1 H}$ NMR (DMSO-d6) $\delta 1.31$ (t, $J=7 \mathrm{~Hz}, 3 \mathrm{H}$, $\left.\mathrm{CH}_{3}\right), 2.6\left(\mathrm{~s}, 3 \mathrm{H}, \mathrm{CH}_{3}\right), 3.26\left(\mathrm{~s}, 3 \mathrm{H}, \mathrm{N}-\mathrm{CH}_{3}\right), 3.45$ (s, $\left.3 \mathrm{H}, \mathrm{N}-\mathrm{CH}_{3}\right), 4.30$ (q, J=7 Hz, 2H, $\left.\mathrm{CH}_{2}\right), 4.80$ (s, $1 \mathrm{H}$, $\mathrm{CH}), 12.8(\mathrm{~s}, 1 \mathrm{H}, \mathrm{NH}) ;{ }^{13} \mathrm{C}$ NMR(DMSO-d6, $75 \mathrm{Mz}$ ) S16.0 $\left(\mathrm{CH}_{3}\right), 29.0\left(\mathrm{CH}_{3}\right), 31.0\left(\mathrm{CH}_{3}\right), 59.0\left(\mathrm{CH}_{2}\right), 70.5$ (CH), 95.0 (C4a), 148.0 (C8a), 153.8 (C2), 159.8 (C7-S), 161.0 (C4), 163.5 (C5), $179.0\left(\mathrm{CH}_{3} \mathrm{CO}\right)$, 189.5 (COOEt); MS m/z (\%) $368\left(\mathrm{M}^{+}, 35\right)$; Anal. Calcd for $\mathrm{C}_{14} \mathrm{H}_{16} \mathrm{~N}_{4} \mathrm{O}$ S (338.37): C, 45.65; $\mathrm{H}, 4.38$; N, 15.21; S, 8.70. Found C, 45.5; H, 4.2; N, 15.0; S, $8.5 \%$.

N-Phenyl 1,3-dimethyl-2,4,5(1 H,3H,6H)trioxopyrimido[4,5-d-pyrimidin-7-yl] thio-3oxobutanamide (11f).

Yellow solid (3.0 g, 72.30\%), m.p. $229 \%$ C; (KBr) í 3400, 3250 (2NH), 1725, 1672, 1652, 1630 (CO) cm"1; ${ }^{1} \mathrm{H}$ NMR (DMSO-d6) $\delta 2.53$ (s, 3H, $\mathrm{CH}_{3}$ ), 3.25 (s, 3H, N-CH $)_{3}, 3.42\left(\mathrm{~s}, 3 \mathrm{H}, \mathrm{N}-\mathrm{CH}_{3}\right), 4.6$ (s, $1 \mathrm{H}, \mathrm{CH}), 7.27-7.50(\mathrm{~m}, 5 \mathrm{H}, \mathrm{ArH}), 9.0(\mathrm{~s}, 1 \mathrm{H}, \mathrm{NH})$, 10.1 (s, $1 \mathrm{H}, \mathrm{NH}) ;{ }^{13} \mathrm{C}$ NMR(DMSO-d6, $\left.75 \mathrm{Mz}\right) \delta$ $20.0\left(\mathrm{CH}_{3}\right), 28.0\left(\mathrm{CH}_{3}\right), 29.7\left(\mathrm{CH}_{3}\right), 68.5(\mathrm{CH}), 94.5$ (C4a), (120.0, 126.5, 128.5, 130.0 C-Ar.), 148.0 (C8a), 152.0 (C2), 161.0 (C7-S), 161.5 (C4), 164.0 (C5), 165.8 (NHCO), $179.5\left(\mathrm{COCH}_{3}\right) . \mathrm{MS} \mathrm{m} / \mathrm{z}(\%)$ $415\left(\mathrm{M}^{+}, 40\right)$; Anal.Calcd for $\mathrm{C}_{18} \mathrm{H}_{17} \mathrm{~N}_{5} \mathrm{O}_{5} \mathrm{~S}$ (415.42): C, 52.04; H, 4.12; N, 16.86; S, 7.72. Found C, 52.0; H, 3.9; N, 16.5; S, 7.5\%.
Synthesis of the thiohydrazonates (7)

To a solution of each of $\mathbf{1 1 b}, \mathbf{1 1 d}$ and $\mathbf{1 1 f}$ (10 $\mathrm{mmol})$ in ethanol $(40 \mathrm{ml})$ was added sodium acetate trihydrate $(1.38 \mathrm{~g}, 10 \mathrm{mmol})$ and the mixture was cooled to $0-5 \% \mathrm{C}$ in an ice bath. To the resulting cold solution was added portionwise a cold solution of benzenediazonium chloride, prepared by diazotizing aniline $(10 \mathrm{mmol})$ dissolved in hydrochloric acid $(6$ $\mathrm{M}, 6 \mathrm{ml})$ with a solution of sodium nitrite $(0.7 \mathrm{~g}, 10$ $\mathrm{mmol})$ in water $(10 \mathrm{ml})$. After complete addition of the diazonium salt, the reaction mixture was stirred for further $12 \mathrm{~h}$ at room temperature. The solid precipitated was filtered off, washed with water, dried and crystallized from dimethyformamide/EtOH (1:1 $v: v)$ to give the respective pure $\mathbf{7 b}, \mathbf{7 d}$ and $\mathbf{7 f}$.

3 - D i m e t h y I- $2,4,5$ ( 1 H , 3 H , 6 H ) trioxopyrimido[4,5-d]pyrimidin-7-yl]-N-phenyl2-oxopropanethiohydrazonate (7b).

Yellow solid (3.0 g, $75.0 \%$ ), m.p. $298 \%$ C; $(\mathrm{KBr})$ í 3350, 3235 (2NH), 1710, 1660, 1630, 1590 (CO) cm"1; ${ }^{1} \mathrm{H}$ NMR (DMSO-d6) $\delta 2.50$ (s, 3H, $\mathrm{CH}_{3}$ ), 3.26 (s, 3H, N-CH $)_{3}$, 3.45 (s, 3H, N-CH $\mathrm{CH}_{3}, 7.27-7.40$ (m, 5H, ArH), 9.45 (s, 1H, NH), 10.2 (s, 1H, NH); MS $\mathrm{m} / \mathrm{z}(\%) 400\left(\mathrm{M}^{+}, 20\right)$; Anal. Calcd for $\mathrm{C}_{17} \mathrm{H}_{16} \mathrm{~N}_{6} \mathrm{O}_{4} \mathrm{~S}$ (400.41): C, 50.99; H, 4.03; N, 20.99; S, 8.01. Found C, 50.6; H, 3.9; N, 20.7; S, 8.0\%.

3-Dimethyl-2,4,5(1H,3H,6H)-trioxopyrimido[4,5-d] pyrimidin-7-yl]-N-phenyl-2-ethoxy-3-oxoethanethiohydrazonate (7d).

Yellow solid (3.2 g, 74.4\%), m.p. > $300^{\circ} \mathrm{C}$; (KBr) í 3390, 3255 (2NH), 1705, 1680, 1640, 1585 (CO) cm"1; ${ }^{1} \mathrm{H}$ NMR (DMSO-d6) $\delta 1.33$ (t, $J=7 \mathrm{~Hz}$, $3 \mathrm{H}), 3.25\left(\mathrm{~s}, 3 \mathrm{H}, \mathrm{N}-\mathrm{CH}_{3}\right), 3.45\left(\mathrm{~s}, 3 \mathrm{H}, \mathrm{N}-\mathrm{CH}_{3}\right), 4.49$ (q, $J=7 \mathrm{~Hz}, 2 \mathrm{H}), 7.2-7.70(\mathrm{~m}, 5 \mathrm{H}, \mathrm{ArH}), 10.2$ (s, $1 \mathrm{H}, \mathrm{NH}), 11.0$ (s, $1 \mathrm{H}, \mathrm{NH})$; MS m/z (\%) $430\left(\mathrm{M}^{+}, 33\right)$; Anal. Calcd for $\mathrm{C}_{18} \mathrm{H}_{18} \mathrm{~N}_{6} \mathrm{O}_{5} \mathrm{~S}$ (430.44): C, 50.23; $\mathrm{H}$, 4.21; N, 19.52; S, 7.45. Found C, 50.1; H, 3.89; N, 19.3 ; S, $7.2 \%$.

3-Dimethyl-2,4,5(1H,3H,6H)-trioxopyrimido[4,5-d] pyrimidin-7-yl]-N-phenyl-2-(phenylamino)-2-oxoethanethiohydrazonate (7f).

Yellow solid (3.5 g, 73.3\%), m.p. > $300^{\circ} \mathrm{C}$; (KBr) í 3350, 3245 (2NH), 1707, 1670, 1645, 1595 (CO) cm"1; ${ }^{1} \mathrm{H}$ NMR (DMSO-d6) $\delta 3.26\left(\mathrm{~s}, 3 \mathrm{H}, \mathrm{N}-\mathrm{CH}_{3}\right.$ ), $3.45\left(\mathrm{~s}, 3 \mathrm{H}, \mathrm{N}-\mathrm{CH}_{3}\right), 7.3-7.5(\mathrm{~m}, 10 \mathrm{H}, \mathrm{ArH}), 9.0$ (s, 
$1 \mathrm{H}, \mathrm{NH}), 9.35(\mathrm{~s}, 1 \mathrm{H}, \mathrm{NH}), 9.9(\mathrm{~s}, 1 \mathrm{H}, \mathrm{NH}) ; \mathrm{MS} \mathrm{m} / \mathrm{z}$ (\%) $477\left(\mathrm{M}^{+}, 48\right)$; Anal. Calcd for $\mathrm{C}_{22} \mathrm{H}_{19} \mathrm{~N}_{7} \mathrm{O}_{4} \mathrm{~S}$ (477.5): C, 55.34; H, 4.01; N, 20.53; S, 6.72. Found C, 55.1; H, 3.7; N, 20.2; S, 6.5\%.

Synthesis of 7,9-dimethylpyrimido[4,5-d][1,2,4] triazolo[4,3-a]pyrimidine-5,6,8(1H,7H,9H)-trione (5a-g).

Method A

To a mixture of 7,8-dihydro-1,3-dimethyl7-thioxopyrimido[4,5-d]pyrimidine-2,4,5(1H,3H,6H) trione (4) (2.4 g, $0.01 \mathrm{~mol})$ and appropriate hydrazonoyl halide $1(0.01 \mathrm{~mol})$ in dioxane $(40 \mathrm{ml})$, trimethylamine $(1.4 \mathrm{ml}, 0.01 \mathrm{~mol})$ was added. The reaction mixture was refluxed under stirring till hydrogen sulfide ceased to evolve (6-10 h). The solvent was evaporated and the residue was treated with ice/ $\mathrm{HCl}$ mixture. The solid product was collected, washed with water and crystallized from proper solvent to give the respective 5 in $50-60 \%$ yield.

\section{Method B (for 5b, 5d and 5f)}

To a stirred ethanolic sodium ethoxide solution, prepared from sodium metal $(0.23 \mathrm{~g}, 10$ $\mathrm{mg}$ atom) and absolute ethanol $(20 \mathrm{ml})$, was added each of the compound $\mathbf{7 b}, \mathbf{7 d}$ and $\mathbf{7 f}(10 \mathrm{mmol})$ and the reaction mixture was stirred at room temperature for $15 \mathrm{~h}$, during which the starting reactants 7 dissolved and the crude product preciptated. The latter was filtered, washed with water, dried and finally crystallized from the proper solvent to give a product identified as $\mathbf{5 b}, \mathbf{5 d}$ and $\mathbf{5 f}$, respectively. The latter products proved to be identical in all respects ( $\mathrm{mp}$, mixed $\mathrm{mp}$, IR) with that obtained from 4 and the respective hydrazonoyl halides 1 . Their yields were $60-70 \%$.

9-Dimethyl-1,3-diphenylpyrimido[4,5-d][1,2,4] triazolo[4,3-a]pyrimidine-5,6,8(1H,7H,9H)-trione (5a)

Pale yellow solid (2.3 g, 57.5\%), m.p. > 300 ${ }^{\circ} \mathrm{C}$; (KBr) í1695, 1630 (CO) cm"1; ; ${ }^{1} \mathrm{H}$ NMR (DMSO-d6) $\delta 3.28\left(\mathrm{~s}, 3 \mathrm{H}, \mathrm{N}-\mathrm{CH}_{3}\right), 3.40\left(\mathrm{~s}, 3 \mathrm{H}, \mathrm{N}-\mathrm{CH}_{3}\right), 7.27-8.0$ (m, 10H, ArH); ${ }^{13} \mathrm{C}$ NMR (DMSO-d6, $\left.75 \mathrm{MHz}\right) \delta$ $27.2\left(\mathrm{CH}_{3}\right), 29.3 .0\left(\mathrm{CH}_{3}\right), 94.2(\mathrm{C} 5 \mathrm{a}), 127.2,127.3$, 128.38, 130.49, 131.85, 132.42, 136.73 (C-Ar), 144.0 (N1-C), 148.0 (C9a), 150.0 (C8), 160.0 (C3), 161.5 (C5), 163.0 (C6); MS m/z (\%) $400\left(\mathrm{M}^{+}, 19\right)$; Anal. Calcd for $\mathrm{C}_{21} \mathrm{H}_{16} \mathrm{~N}_{6} \mathrm{O}_{3}$ (400.39): C, 62.99; H, 4.03; N, 20.99. Found C, 62.75; H, 3.9; N, 20.7\%.
3-Acetyl-7,9-dimethyl-1-phenylpyrimido[4,5-d] $[1,2,4]$ triazolo[4,3-a] pyrimidine-5,6,8(1H,7H,9H)trione (5b)

Pale yellow solid (2.2 g, 60.1\%), m.p. > 300 ${ }^{\circ} \mathrm{C}$; (KBr) í 1710, 1690, 1640 (CO) cm"1; ${ }^{1} \mathrm{H}$ NMR (DMSO-d6) $\delta 2.5$ (s, 3H, $\mathrm{CH}_{3}$ ), $3.1\left(\mathrm{~s}, 3 \mathrm{H}, \mathrm{N}-\mathrm{CH}_{3}\right.$ ), $3.4\left(\mathrm{~s}, 3 \mathrm{H}, \mathrm{N}-\mathrm{CH}_{3}\right), 7.25-7.85(\mathrm{~m}, 5 \mathrm{H}, \mathrm{ArH}) ;{ }^{13} \mathrm{C} \mathrm{NMR}$ (DMSO-d6, $75 \mathrm{MHz}$ ) ä21.0 $\left(\mathrm{CH}_{3}\right), 33.49\left(\mathrm{CH}_{3}\right), 34.28$ $\left(\mathrm{CH}_{3}\right), 90.9$ (C5a), 117.0, 119.0, 123.0, 125.5, 127.5, 132.0, (C-Ar), 138.5 (N1-C), 150.0 (C9a), 155.2 (C8), 161.5 (C3), 162.5 (C5), 163.6 (C6), $172.0\left(\mathrm{COCH}_{3}\right)$; MS m/z (\%) $366\left(\mathrm{M}^{+}, 35\right)$; Anal. Calcd for $\mathrm{C}_{17} \mathrm{H}_{14} \mathrm{~N}_{6} \mathrm{O}_{4}$ (366.33): C, 55.74; H, 3.85; N, 22.94. Found C, 55.5; $\mathrm{H}, 3.6$; N, 22.65\%.

3-Acetyl-7,9-dimethyl-1-(4-methylphenyl) pyrimido[4,5-d][1,2,4]-triazolo[4,3-a]pyrimidine5,6,8(1H,7H,9H)-trione (5c)

Pale yellow solid (2.3 g, 60.5\%), m.p. > 300 ${ }^{\circ} \mathrm{C}$; (KBr) í 1710, 1685, 1635 (CO) cm"1; ${ }^{1} \mathrm{H}$ NMR (DMSO-d6) $\delta 2.5\left(\mathrm{~s}, 3 \mathrm{H}, \mathrm{CH}_{3}\right), 2.6\left(\mathrm{~s}, 3 \mathrm{H}, \mathrm{CH}_{3}\right)$, $3.27\left(\mathrm{~s}, 3 \mathrm{H}, \mathrm{N}-\mathrm{CH}_{3}\right), 3.40\left(\mathrm{~s}, 3 \mathrm{H}, \mathrm{N}-\mathrm{CH}_{3}\right), 7.4-7.6(\mathrm{~d}$, $\mathrm{J}=8 \mathrm{~Hz}, 2 \mathrm{H}, \mathrm{ArH}), 7.7-8.09$ (d, J = $8 \mathrm{~Hz}, 2 \mathrm{H}, \operatorname{ArH}$ ); MS m/z (\%) $380\left(\mathrm{M}^{+}, 30\right)$; Anal. Calcd for $\mathrm{C}_{18} \mathrm{H}_{16} \mathrm{~N}_{6} \mathrm{O}_{4}$ (380.36): C, 56.84; H, 4.24; N, 22.10. Found C, 56.8; $\mathrm{H}, 4.0 ; \mathrm{N}, 22.0 \%$.

9 - D i m e t h y I - 3 - e t h ox y c a r b o n y I- 1 phenylpyrimido[4,5-d][1,2,4]-triazolo[4,3-a] pyrimidine-5,6,8(1H,7H,9H)-trione (5d)

Pale yellow solid (2.2 g, 55.5\%), m.p. $299^{\circ} \mathrm{C}$; (KBr) í1730, 1695, 1650 (CO) cm"1; ${ }^{H} \mathrm{H}$ NMR (DMSOd6) $\delta 1.3(\mathrm{t}, J=7 \mathrm{~Hz}, 3 \mathrm{H}), 3.32\left(\mathrm{~s}, 3 \mathrm{H}, \mathrm{N}-\mathrm{CH}_{3}\right), 3.55$ (s, 3H, N-CH $)_{3}, 4.35$ (q, J = $\left.7 \mathrm{~Hz}, 2 \mathrm{H}\right), 7.25-7.80$ (m, 5H, ArH); ${ }^{13} \mathrm{C}$ NMR (DMSO-d6, $75 \mathrm{MHz}$ ) $\delta 28.1$ $\left(\mathrm{CH}_{3}\right), 29.88\left(\mathrm{CH}_{3}\right), 31.5\left(\mathrm{CH}_{3}\right), 59\left(\mathrm{CH}_{2}\right), 92.9(\mathrm{C} 5 \mathrm{a})$, 116.5, 119.0, 123.6, 125.8, 126.3, 127.6, 131.0, 132.5, (C-Ar), 144.0 (N1-C), 151.0 (C9a), 154.5 (C8), 161.0 (C3), 162.2 (C5), 163.3 (C6), 174.0 (COOEt); MS $m / z(\%) 396\left(\mathrm{M}^{+}, 15\right)$; Anal. Calcd for $\mathrm{C}_{18} \mathrm{H}_{16} \mathrm{~N}_{6} \mathrm{O}_{5}$ (396.36): C, 54.54; H, 4.07; N, 21.2. Found C, 54.3; $\mathrm{H}, 3.7 ; \mathrm{N}, 21.0 \%$.

9-Dimethyl-3-ethoxycarbonyl-1-(4-methylphenyl) pyrimido[4,5-d][1,2,4]-triazolo[4,3-a]pyrimidine5,6,8(1H,7H,9H)-trione (5e)

Pale yellow solid (2.1 g, 51.0\%), m.p. 267 ${ }^{\circ} \mathrm{C}$; (KBr) í 1735, 1700, 1645 (CO) cm"1; ${ }^{1} \mathrm{H}$ NMR (DMSO-d6) $\delta 1.3$ (t, J= $7 \mathrm{~Hz}, 3 \mathrm{H}), 2.6\left(\mathrm{~s}, 3 \mathrm{H}, \mathrm{CH}_{3}\right.$ ), 3.27 (s, 3H, N-CH ), 3.45 (s, 3H, N-CH ${ }_{3}$ ), 4.4 (q, J = 
$7 \mathrm{~Hz}, 2 \mathrm{H}), 7.20-7.45$ (d, J = $8 \mathrm{~Hz}, 2 \mathrm{H}, \mathrm{ArH}), 7.6-7.8$ (d, J = $8 \mathrm{~Hz}, 2 \mathrm{H}, \mathrm{ArH})$; MS $\mathrm{m} / \mathrm{z}(\%) 410\left(\mathrm{M}^{+}, 25\right)$; Anal. Calcd for $\mathrm{C}_{18} \mathrm{H}_{16} \mathrm{~N}_{6} \mathrm{O}_{5}$ (410.38): C, 55.61; $\mathrm{H}$, 4.42; N, 20.48. Found C, 55.5; H, 4.1; N, 20.3\%.

9-Dimethyl-3- phenylaminocarbonyl-1phenylpyrimido[4,5-d][1,2,4]-triazolo[4,3-a] pyrimidine-5,6,8(1H,7H,9H)-trione $(5 \mathrm{f})$

Yellow solid $(2.2 \mathrm{~g}, 50.0 \%)$, m.p. $>300^{\circ} \mathrm{C}$; (KBr) i 3255 (NH), 1705, 1675, 1630 (CO) cm"1; ${ }^{1} \mathrm{H}$ NMR (DMSO-d6) $\delta 3.25\left(\mathrm{~s}, 3 \mathrm{H}, \mathrm{N}-\mathrm{CH}_{3}\right), 3.40$ (s, $\left.3 \mathrm{H}, \mathrm{N}-\mathrm{CH}_{3}\right), 7.25-7.80(\mathrm{~m}, 10 \mathrm{H}, \mathrm{ArH}), 10.6(\mathrm{~s}, 1 \mathrm{H}$, $\mathrm{NH}) ;{ }^{13} \mathrm{C}$ NMR (DMSO-d6, $\left.75 \mathrm{MHz}\right) \delta 33.0\left(\mathrm{CH}_{3}\right)$, $39.0\left(\mathrm{CH}_{3}\right), 91.0$ (C5a), 127.5, 130.0, 132.5, 138.0 (C-Ar), 144.0 (N1-C), 150.5 (C9a), 154.0 (C8), 161.5 (C3), 162.5 (C5), 163.9 (C6); MS m/z (\%) $443\left(\mathrm{M}^{+}\right.$, 27); Anal. Calcd for $\mathrm{C}_{22} \mathrm{H}_{17} \mathrm{~N}_{7} \mathrm{O}_{4}$ (443.41): C, 59.59; $\mathrm{H}, 3.86$; N, 22.11. Found C, 59.3; H, 3.5; N, 21.8\%.

7,9-Dimethyl-3- phenylaminocarbonyl1-(4-methylphenyl)-pyrimido[4,5-d][1,2,4]triazolo[4,3-a]pyrimidine-5,6,8(1H,7H,9H)-trione (5g)

Yellow solid $(2.5 \mathrm{~g}, 54.7 \%)$, m.p. $>300^{\circ} \mathrm{C}$; (KBr) í $3250(\mathrm{NH}), 1705,1665,1615(\mathrm{CO}) \mathrm{cm}^{\prime \prime 1} ;{ }^{1} \mathrm{H}$ NMR (DMSO-d6) $\delta 3.26\left(\mathrm{~s}, 3 \mathrm{H}, \mathrm{N}-\mathrm{CH}_{3}\right), 3.45$ (s, 3H, $\left.\mathrm{N}-\mathrm{CH}_{3}\right), 7.25-8.0(\mathrm{~m}, 9 \mathrm{H}, \mathrm{ArH}), 10.31(\mathrm{~s}, 1 \mathrm{H}, \mathrm{NH})$; MS $m / z(\%) 457\left(\mathrm{M}^{+}, 30\right)$; Anal. Calcd for $\mathrm{C}_{23} \mathrm{H}_{19} \mathrm{~N}_{7} \mathrm{O}_{4}$ (457.44): C, 60.39; H, 4.19; N, 21.43. Found C, 60.0; $\mathrm{H}, 4.0 ; \mathrm{N}, 21.1 \%$.

\section{Antimicrobial assay}

Cultures of four fungal species namely Aspergillusfumigatus AF, Penicilliumitalicum PI,Syncephalastrumracemosum SR and Candida albicans. CA as well as four bacterial species namely Staphylococcus aureus SA, Pseudomonas aeruginosa PA, Bacillus subtilis BS and Escherichia coli EC were used to investigate the antimicrobial activity of the compounds 5a-g. The antimicrobial activity was assayed biologically using the diffusion plate technique. The latter technique was carried out by pouring a spore suspension of the fungal species (one $\mathrm{ml}$ of sterile water contains approximately 108 conidia) or spreading bacterial suspension over a solidified malt agar medium. The layer is allowed to set for $30 \mathrm{~min}$. A solution of the test compound 5 a-g $(1.0 \mathrm{ug} / \mathrm{ml})$ in dimethylformamide was placed onto sterile $5 \mathrm{~mm}$ filter paper discs and allowed to dry, then the discs were placed on the centre of the malt agar plate and incubated at optimum incubation temperature $28 \pm 2^{\circ} \mathrm{C}$. Test organism growth may be affected by the inhibitory action of the test compound, so a clear zone around the disc appears as an indication of the inhibition of test organism growth. The size of the clearing zone is proportional to the inhibitory action of the compound. The fungicide Terbinafin and the bactericide Chloramphenicol were used as standards under the same conditions. Measurements were considered after $72 \mathrm{~h}$ for fungi and $24 \mathrm{~h}$ for bacteria. The results are summarized in table 1.

\section{RESULTS AND DISCUSSION}

The starting 7,8-dihydro-1,3-dimethyl-7thioxopyrimido[4,5- $d$ ] pyrimidine- $2,4,5(1 \mathrm{H}, 3 \mathrm{H}, 6 \mathrm{H})$ trione(4) which has not been reported hither to was prepared by heating of 6-amino-1,3-dimethyluracil (2)with ethyl chloroformate in pyridine to get ethyl 6-amino-1,3-dimethyl-5-(ethoxycarbonyl) uracil (3), ${ }^{12}$ followed by reaction with potassium thiocyanate in<smiles>[R]c1cc(=O)n2c([R])c[X]c2n1</smiles>

I
170 - 175<smiles>[R]c1c[X]c2nc(=O)cc([R])n12</smiles>

II
$162-163$<smiles>[R]c1nn([Al])c2nc3c(c(=O)n(C)c(=O)n3C)c(=O)n12</smiles>

Chart $1:{ }^{13} \mathrm{C}$ comparison between different triazole derivatives 
1,4-dioxane containing $10 \% \mathrm{HCl} .{ }^{13}$ The structure of compound $\mathbf{4}$ was confirmed by spectral and elemental analysis data (see Experimental). The hydrazonoyl halides $\mathbf{1} \mathbf{a}-\mathbf{g}^{14-16}$ were prepared by literature methods.Reaction of $\mathbf{4}$ with each of the hydrazonoyl halides 1a-g was carried out in 1,4dioxane in the presence of triethylamine while heating the reaction mixture under reflux till in allcases, hydrogen sulfide evolved during the course of the reaction and so stirring of the reactionmixture was continued till hydrogen sulfide ceased to evolve (6-10 h). Work up of the reaction mixture afforded, in each case, one isolable product as evidenced by tlc analysis of the crude product. On the basis of elemental analyses and IR, ${ }^{1} \mathrm{H}$ and ${ }^{13} \mathrm{CNMR}$ spectra which showed all the expected signals (see Experimental), the isolated products were assigned the structure of 7,9-dimethylpyrimido[4,5- $d$ ] $[1,2,4]$ triazolo[4,3-a]pyrimidine-5,6,8 $(1 H, 7 H, 9 H)$ trione (5) rather than the isomeric structure of 1,3-dimethylpyrimido[5,4-e][1,2,4]triazolo[4,3-a] pyrimidine-2,4,5(1H,3H,7H)-trione (6) (scheme 1). For example, the $\delta$ value (163.0) for the carbonyl carbon signal in the ${ }^{13} \mathrm{C} \mathrm{nmr} \mathrm{spectrum} \mathrm{of} 5$ a, takenas an example of the series prepared is similar to that of I ( $\delta 161-164)$ and different fromits isomeric structure II $(\delta 170-175)^{14}($ chart 1$)$. This finding ruled out the acylimino typestructure $\mathbf{5}$ for the isolated products.

The formation of compounds 5 from the thione 2 and hydrazonoyl halides 1 could beaccounted for by one of the two pathways indicated in scheme

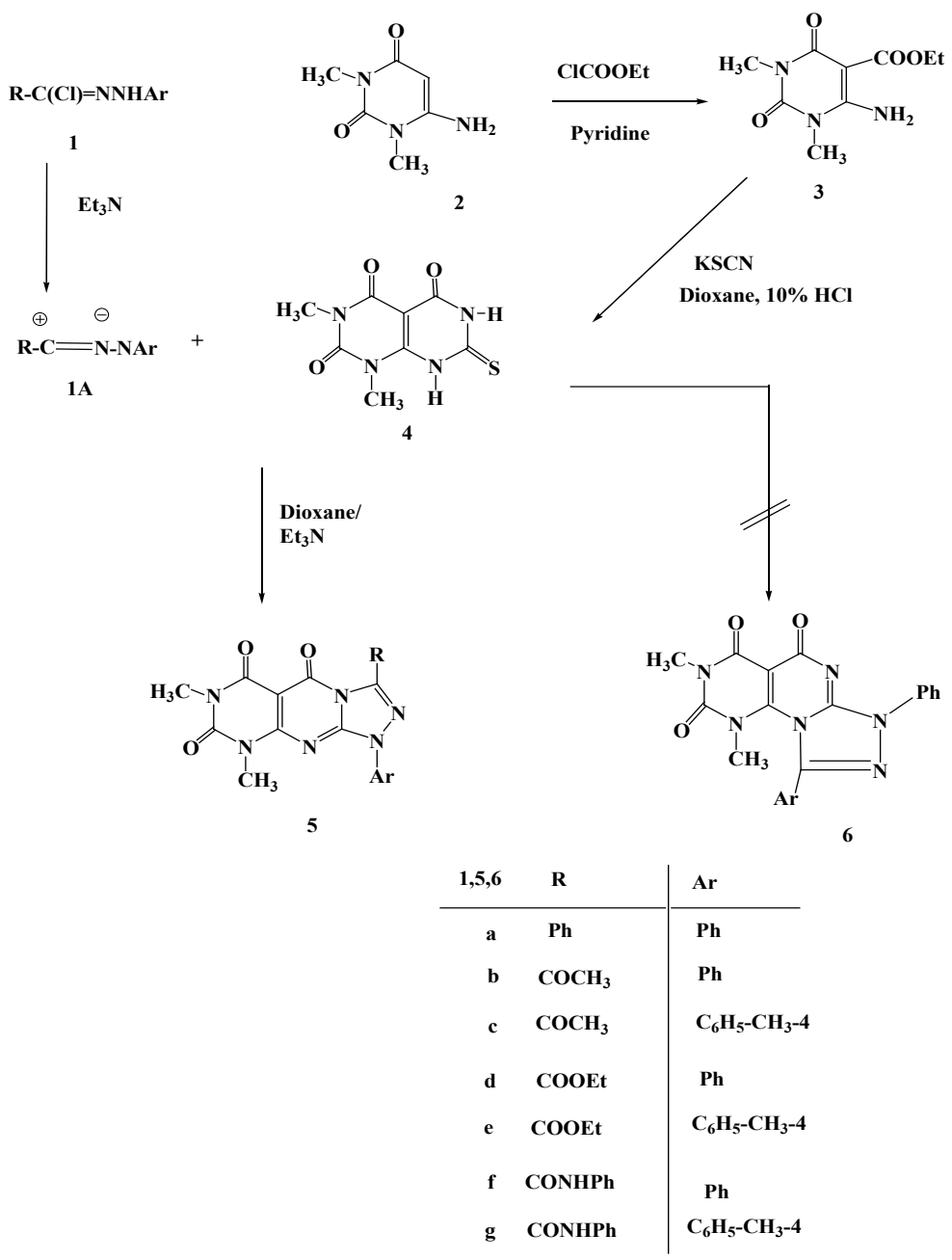

Scheme 1: Synthesis of 7,8-dihydro-1,3-dimethyl-7-thioxopyrimido[4,5-d]pyrimidine$2,4,5(1 \mathrm{H}, 3 \mathrm{H}, 6 \mathrm{H})$ trione $(4)$ and its reaction with hydrazonoyl chloride (1) 
2. As depicted in this scheme, it is suggested that the studied reactions started with the hydrazonoylation of 2 to give therespective thiohydrazonate esters 7 . This is followed by Smiles type rearrangement ${ }^{17,18}$ of 7 to form the respective thiohydrazides 8 , which in turn underwent cyclization to give $\mathbf{5}$ as end products (route a, Scheme 2).

It seems that both intermediates $\mathbf{7}$ and $\mathbf{8}$ are consumed,under the employed reaction conditions as soon as they are formed since all attempts to isolate them failed. Alternatively, reaction of the thione 2 with hydrazonoyl halides 1 starts with the formation of the amidrazone intermediates $\mathbf{9}$ which cyclize to give 5 (route b, Scheme 1). This alternative pathway has been ruled out, however, on the basis that alkylation and acylation of 2-thiouracil derivatives have been known to give S-alkyl and S-acyl derivatives, respectively. ${ }^{19-22}$ Furthermore the suggested route a and the involvement of 7 and 8 as intermediates in the formation of 4 by this route were evidenced by alternate synthesis of $\mathbf{5 b}, \mathbf{5 d}$ and $5 f$ (Scheme 3).

Thus, treatment of 2 with each of 3-chloro2,4-pentanedione (10b), ethyl $\alpha$-chloroacetoacetate (10d) and á-chloroacetoacetanilide(10f) in chloroform in the presence of triethylamine afforded the respective substituted products 11b, 11d and 11f. Coupling of each of these compounds with benzenediazonium chloride in ethanol in thepresence of sodium acetate yielded the thiohydrazonates $\mathbf{7 b}, \mathbf{7 d}$ and 7f, respectively (Scheme 2) via Japp-Klingemann cleavage of the acetyl group. ${ }^{22}$ Treatment of the products 7 with sodium ethoxide in ethanol afforded the respective compounds $\mathbf{5 b}, \mathbf{5 d}$ and $\mathbf{5 f}$ identical in all respects with those obtained from reactions<smiles>[R]C(=S)N([Al])[Y]([H])n1c(=O)n(C)c(=O)c2c(=O)n(C)c(N([AlH])N([AlH])C([R])=S)nc21</smiles> 
of $\mathbf{2}$ with each of $\mathbf{1 b}, \mathbf{1 d}$ and $\mathbf{1 f}$, respectively. This finding indicates that $\mathbf{7}$ and $\mathbf{8}$ are intermediates in the studied reactionsof $\mathbf{1}$ with $\mathbf{3}$ and they are consumed as soon as they are formed under the employed reaction conditions. Finally, the suggestion that the site of cyclization of the thiohydrazide intermediates 8 involves N-3 rather than $\mathrm{N}-1$ to give 5 is consistent with literature reports. For example, ithas been reported that cyclization of 2-substituted-uracil derivatives having no substituenton $\mathrm{N}-3$ proceeds regioselectively to give the respective $1,2,4$ triazolo[4,3-a]pyrimidin-5(1H)-ones. ${ }^{23-25}$

In conclusion, the studied reactions of hydrazonoyl halides $\mathbf{1}$ with the thione $\mathbf{2}$ are both site and regioselective and lead to the title ring system.

\section{Antimicrobial activity}

The compounds $\mathbf{5 a} \mathbf{a g}$ were tested for their antimicrobial activities against four fungal speciesnamely Aspergillusfumigatus AF, Penicilliumitalicum PI, Syncephalastrumracemosum SR and Candida albicans CA as well as four bacteria species namely Staphylococcus aureus SA, Pseudomonas aeruginosa PA, Bacillus subtilis BS and Escherichia coli EC.The organisms were tested against the activity of solutions of concentration of $1.0 \mu \mathrm{g} / \mathrm{ml}$ of each compoundand using inhibition zone diameter in $\mathrm{cm}$ (IZD) as criterion for the antimicrobial activity. Terbinafin as an antifungal agent and Chloramphenicol as an antibacterial agent were used asreferences to evaluate the potency of the tested compounds under the same<smiles>CC(=O)OC=C(C)C(=O)Cl</smiles>

\section{$\mathrm{CHCl}_{3} / \mathrm{Et} 3 \mathrm{~N}$}

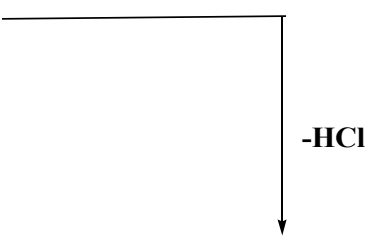<smiles>[R]/C(=N\Nc1ccccc1)Sc1nc2c(c(=O)[nH]1)c(=O)n(C)c(=O)n2C</smiles>

7<smiles>[R]C(=S)NN([Tl])c1nc2c(c(=O)n(C)c(=O)n2C)n1[IH]</smiles>

$\mathrm{PhN}_{2} \mathrm{Cl}$

EtOH/ NaOAc

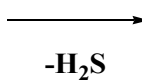<smiles>[R]C(SC1=Nc2c(c(=O)n(C)c(=O)n2C)NN1C)C(C)=O</smiles>

11<smiles></smiles>

$$
\mathrm{R}, \mathrm{b}=\mathrm{CH}_{3} \mathrm{CO}, \mathrm{d}=\mathrm{EtOCO}, \mathrm{f}=\mathrm{PhNHCO}
$$

Scheme 3: Alternative method of synthesis of 7,9-dimethylpyrimido[4,5-d][1,2,4]triazolo[4,3-a]pyrimidine$5,6,8(1 \mathrm{H}, 7 \mathrm{H}, 9 \mathrm{H})$-trione (5) 
Table 1: Antimicrobial activity of the products $5 \mathrm{a}-\mathrm{g}$

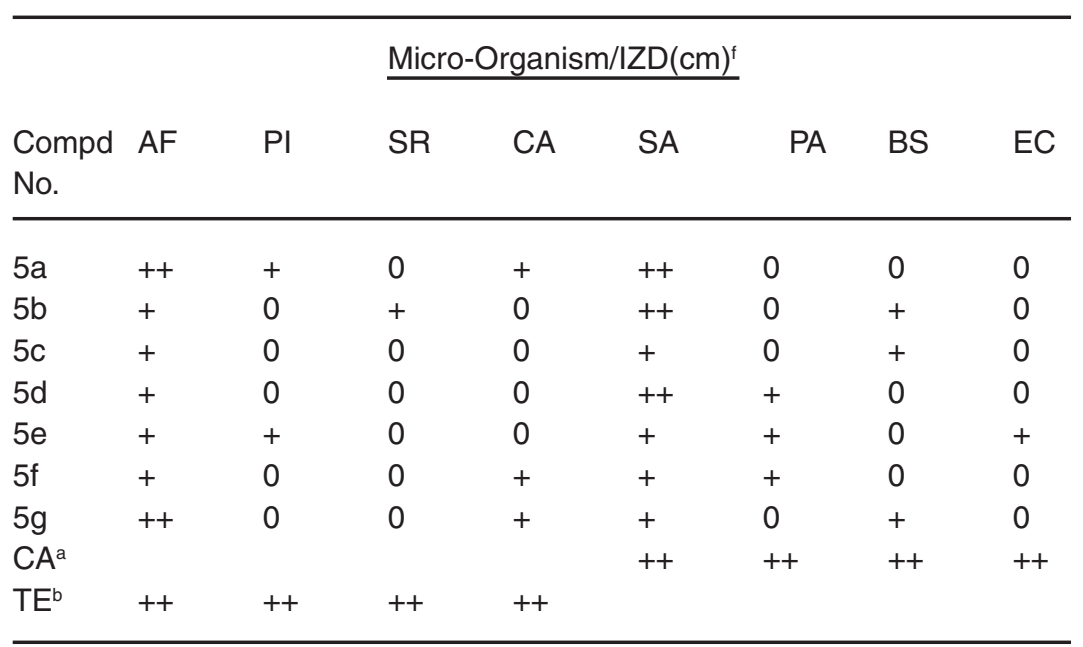

f50 ml of solution in DMF whose concentration $1.0 \mu \mathrm{g} / \mathrm{ml}$ was tested.

a Chloramphenicol as standard antibacterial agent, bTerbinfin as standard antifungal agent, ++ inhibition value $0.6-1.0 \mathrm{~cm} ;+$, inhibition value $0.1-0.5 \mathrm{~cm}$ beyond control; 0 , no inhibition detected.

conditions. Theresults are depicted in table 1. The results reveal that compounds $\mathbf{5 a}, \mathbf{5 b}, \mathbf{5 d}$ and $\mathbf{5 g}$ exhibited thehighest degree of inhibition against the tested organisms AF and SA, respectively, their activity is similarto that of the standard antifungal and antibacterial agents used. All other compounds eitherexhibit no activity or being less active against the tested species.

\section{CONCLUSION}

The present project has outlined the importance of tandem in situ generation and 1,5electrocyclization of $\mathrm{N}$-hetarylnitrilimines as a convenient methodology for synthesis of numerous 1,2,4-triazole derivatives, namely functionalized 7,9-dimethylpyrimido[4,5-d][1,2,4]triazolo[4,3-a] pyrimidine-5,6,8(1H,7H,9H)-trione derivatives. Some compounds prepared showed moderate, whereas other compounds showed weak antimicrobial activity.

\section{ACKNOWLEDGEMENT}

The author thanksTaif University, Taif, Saudi Arabia for the financial support under project number 3674435-1.

\section{REFERENCES}

1. Cava, M.P.; Pollack, N.M.; Dieterle, G.A. J. Am.Chem. Soc., 1973, 95, 2558-2560.

2. Ho, T., Tandem Organic Reactions; WileyInterscience; New York1992.

3. Shawali, A. S., ARKIVOC 2010,(i), 33-97.

4. Pedgaonkar, Y.Y.; Leie, A. C.; Desai, N. H. P.; Degani, M. S.;Int. J.Pharm. Bio. Sci. 2014, 5, 422-439.

5. Clark, A., Pharm Res.1996, 13, 1133-1141.
6. Melik-Ogandzhanyan, R. G.; Khachatryan, V. E.; Gapoyan A. S., Russ Chem Rev. 1985,4, 262-276.

7. Rewcastle, G. W.; Bridge, A. J.; Fry, D. W.; Rubin, J. R.; Denny, W. A.,J. Med. Chem. 1997, 40, 1820-1826.

8. Sanghvi, Y. S.; Larson, S. B.; Matsumoto, S. S.; Nord, L. D.;Smee, D. F.; Willis, R. C.; Avery, T. H.; Robins, R. K.; Revankar, G. R., J. Med. 
Chem.1989, 32, 629-637.

9. Tenser, R. B.; Gaydos, A. K.; Hay, A., Antimicrob Agents Chemother., 2001, 45, 3657-3659.

10. De la Cruz, J.P.; Carrasco, T; Ortega, G; Sanchez, De la; Cuesta, F., Lipids 1992, 27, 192-194.

11. Sharma, P.; Rane, N.; Gurram, V. K.;Bioorg. Med. Chem.Lett. 2004, 14, 4185-4190.

12. Ram, V. J.;Goel, A.; Sarkhel, S.; Maulik, P. R., Bioorg. Med. Chem. 2002, 10,1275-1280.

13. Yoneda, F.; Higuchi, M.,Bull. Chem. Soc. Japan 1973, 46, 3849-3853.

14. EL-Gazzar, A.-R.B. A.;Hussein, H. A. R.; Hafez, H. N., Acta Pharm. 2007, 57, 395411.

15. Shawali, A. S.; Elghandour, A. H.; Sayed. A. R., Synthetic Commun. 2001, 31, 731-740.

16. Mosselhi, M. A. N.; Tawfik, N. M.; Shawali, A. S., Monatsch. Chem. 2003, 134, 565-571.

17. Shawali, A. S., Mosselhi, M. A. N., Tawfik, N. M., J. Org. Chem. 2001,66, 4055-4057.

18. Ishii, K., Hatanaka, M., Ueda, I.,Chem. Pharm.
Bull. 1991,39, 3331-3334.

19. Bunnett., J. F., Quart. Rev. 1958, 12, 1-16.

20. Hurst, D. T.; Beaumont, C., Jones, D. T. E., Kingsley, D. A.; Partridge, J. D., Rutherford, T. J., Aust. J. Chem. 1988,41, 1209-1219.

21. Sodereviciute, V., Vainilavicius, P., Chemija 1993, 2, 70.

22. Ghoneim, K. M.; El-Telbany, F. A.; El-Enany, M., Youssef, K.; Egypt. J. Pharm. Sci. 1987,28, 127-136.

23. Geies, A. A., Kamal-Eldeen, A. M., Abdelhafez, A. A.; Gaber, A. M., Phosphorus, Sulfur \& Silicon 1991, 56, 87-93.

24. Phillip, R. R., In Organic Reactions, R. Adams (Ed.),JohnWiley Sons, NewYork 1959, 10, chap.2, p. 143,

25. Abdel-Aziz, S. A., Allimony, H. A., ElShaar, H. M., Usama, F. A., Abdel- Rahman, R. M., Phosphorus, Sulfur \& Silicon 1996, 113, 6777.

26. Abdelfattah, A. M.; Negm, A. M.; Gaafar, A. E.,Phosphorus, Sulfur \& Silicon 1992, 72, 145-156. 